\title{
STRUGGLE FOR SEEKING KNOWLEDGE IN A FOREIGN COUNTRY IN AHMED SHAWQI'S SYUHADA'UL-'ILMI WAL-GHARBAH: A SEMIOTIC ANALYSIS
}

\author{
Eva Farhah \\ Sebelas Maret University, Indonesia \\ evafarhah@staff.uns.ac.id
}

Article accepted : September - 26-2020

Revised article: November - 13 - 2020

Approved article: November - 19 - 2020

\section{Abstract}

This research aims to reveal the semiotic meaning contained in the poem entitled Syuhada' 'ul'Ilmi wal-Gharbah written by Ahmed Shawqi. Shawqi saw and observed the conditions of the Egyptian people at that time who were experiencing difficulties, sorrow, poverty, ignorance, and British colonialism. Therefore, the Egyptian government sent young people to western countries to study in the hope that after returning to Egypt, they could build their country and nation. In order to reveal the semiotic meaning contained in the poem entitled Syuhadä'ul-'Ilmi wal-Gharbah, the semiotic theory was used through methods of heuristic reading and hermeneutic reading or retroactive reading. Meanwhile, the reading technique was conducted by reading one by one or reading gradually from the heuristic reading to the hermeneutic reading or retroactive reading. The results of the research indicated that knowledge was one of the ways to solve the problems of poverty, ignorance, and resistance to British colonialism in Egypt. However, in reality, young Egyptians who were sent to western countries had accidents and killed them. Therefore, Shawqi emphasized that Egyptian youths remained patient and enthusiastic about seeking knowledge in a foreign country in order to build their state and nation in the future.

Keywords: Semiotic meaning, knowledge, martyrdom, poverty, colonialism

\begin{abstract}
Abstrak
Penelitian ini bertujuan untuk mengungkap makna semiotis yang terkandung di dalam teks puisi berjudul Syuhadā'ul-'Ilmi wal-Gharbah karya Ahmad Syawqi. Syawqi melihat dan mengamati kondisi masyarakat Mesir pada waktu itu yang sedang mengalami kesulitan, kesedihan, kemiskinan, kebodohan, dan penjajahan Inggris. Karena itu, pemerintah Mesir mengirimanak-anak muda ke negeri barat untuk menuntut ilmu dengan harapan setelah kembali dan pulang ke Mesir, mereka dapat membangun Negara dan bangsanya. Untuk mengungkap makna semiotis yang terkandung dalam teks puisi berjudul Syuhadä'ul-'Ilmi wal-Gharbah dimanfaatkan teori semiotik dengan menggunakan metode pembacaan heuristik dan pembacaan hermeneutik atau pembacaan retroaktif. Sementara itu, teknik pembacaan yang dilakukan adalah teknik pembacaan satu persatu atau pembacaan secara bertahap dari pembacaan heuristik terlebih dahulu dan kemudian dilanjutkan dengan pembacaan hermeneutik atau pembacaan retroaktif. Hasil penelitian menunjukkan bahwa ilmu merupakan salah satu cara untuk memecahkan masalah kemiskinan, kebodohan, dan perlawanan terhadap penjajahan Inggris yang ada di Mesir. Namun dalam kenyataannya, anak-anak muda Mesir yang dikirim ke Negara barat justru mengalami kecelakaan dan menewaskan mereka. Dengan kejadian tersebut, Syawqi menekankan agar anak-anak muda Mesir tetap sabar dan semangat untuk menuntut ilmu di negeri asing agar dapat membangun Negara dan bangsanya kelak.
\end{abstract}

Kata Kunci: Makna semiotis, Ilmu, mati syahid, kemiskinan, penjajahan

\section{INTRODUCTION}

Many events, incidents, physical and non

-physical struggles were experienced by ear- lier Arab scholars while seeking knowledge.

Those were beyond human ability because their

intention was solely to seek knowledge and on- 
ly seek the pleasure of Allah. Some of the struggles in seeking knowledge were recorded by Arab scholars in their works. The story of Jabir Abdullah's journey from Hijaz (now Jeddah) to Syria (now Damascus) in his study, for example, was written by Abdul Fattah Abu Ghaddah. In his books, Abu Ghaddah raised and wrote several events and life experiences of Arab scholars in seeking knowledge (Nasrullah, 2018; Sholikhudin, 2016: 154).

Abu Ghaddah stated that there are at least 6 (six) things to be considered regarding the struggles experienced by Arab scholars in seeking knowledge. They are (1) the resilience of Arab scholars to do "knowledge tours" or richlatun fi thalabil-ilmi, (2) the seriousness and thoroughness of Arab scholars by abandoning all kinds of enjoyment, such as sleeping during the day and at night and other enjoyments, (3) the patience and acceptance of Arab scholars towards economic conditions and difficulties of life, (4) the resilience of the Arab scholars to endure hunger and thirst while seeking knowledge, (5) the Arab scholars who ran out of supplies and expenses when seeking knowledge and struggled in isolation because they studied in a foreign country, and (6) the difficulties experienced by Arab scholars when their books were lost, stolen, destroyed by termites or burned (Nasrullah, 2018). Because of the importance and virtue of knowledge for the Arab scholars, wherever the place was, whatever the obstacles, hindrances, and barriers they faced in seeking knowledge, they remained tough, patient, and kept moving until the knowledge was attained. The texts in the hadith of the Prophet Muhammad SAW, the sayings of the Scholars, and in the Noble Quran repeatedly are mentioned as the basis that seeking knowledge is obligatory for every Muslim, both male and female, wherever they are, at any time, at any age, and any obstacle and barrier they must face it with a tough and patient attitude. The texts in question are as follows.

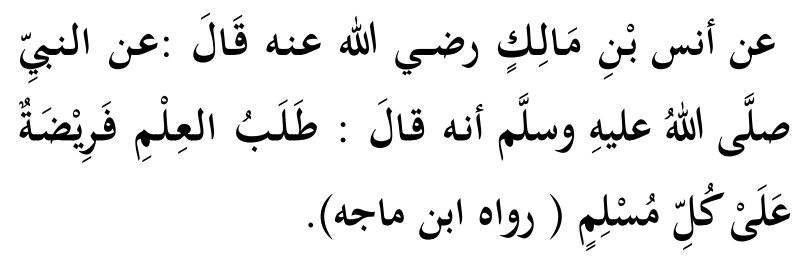

It was narrated from Anas bin Malik that the Messenger of Allah SAW said: "Seeking knowledge is a duty upon every Muslim" (Narrated by Ibnu Majah, Hadith Number 224, validated by Al Albani in Sahih alJami'ish Shaghir No. 3913).

People who have knowledge will be eternal and beneficial to the owner although he/she has passed away. This is mentioned in a Hadith of the Prophet Muhammad concerning the virtue of knowledge in Islam as follows.

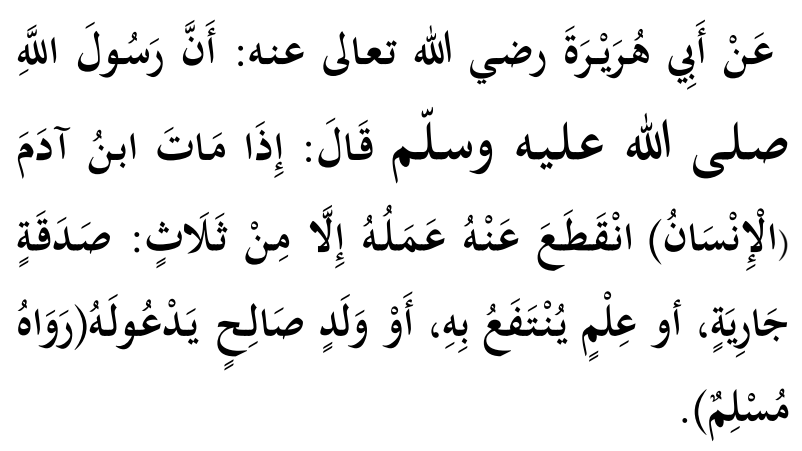

Abu Hurairah (May Allah be pleased with him) reported: The Messenger of Allah SAW said, "When a man dies, his deeds come to an end except for three things: Sadaqah Jariyah (ceaseless charity); a 
knowledge which is beneficial, or a virtuous descendant who prays for him (for the deceased)." (Cf. Narrated by Muslim No. 1631).

In addition to sources from the Hadith of the Prophet Muhammad concerning the virtue and importance of knowledge, there are also sources from the words of the Scholars, namely the words of Imam Shafi'i Rahimahullah as quoted by Imam Nawawi in the muqaddimah of his work entitled al Majmü' 'and Imam Nawawi said as follows.

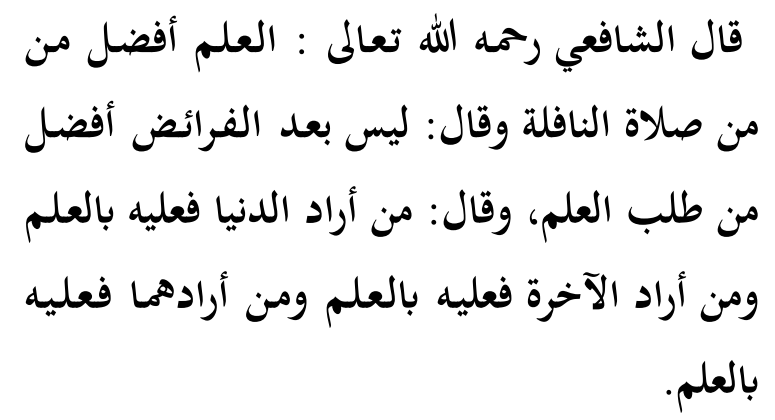

Al-Shafi'i, may God Almighty have mercy on him, said: Knowledge is better than supererogatory prayers, and he said: After the obligatory prayers, there is nothing better than seeking knowledge, and he said: Whoever wishes to have the benefit of this world, let him acquire knowledge, and whoever wishes to have the benefit of the world hereafter, let him acquire knowledge (Rahman, 2011).

In addition to the virtue and importance of knowledge taken from the sources of the Hadith of the Prophet Muhammad and the sayings of the Scholars, there is a more affirming statement taken from a higher source, namely from the Noble Quran as follows.

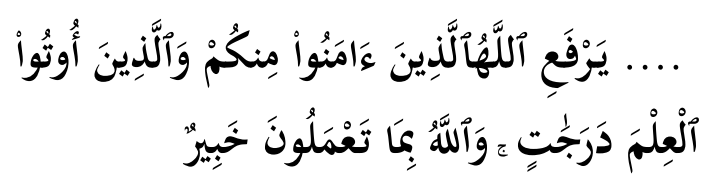

.... Allah will raise those who have be- lieved among you and those who were given knowledge, by degrees. And Allah is ac-

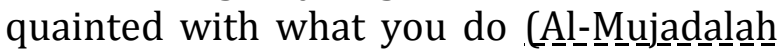
[묘]:11].

The importance of seeking knowledge and the virtue of knowledge for mankind were the background for the poet Ahmed Shawqi to compose a poem entitled Syuhadā'ul-'Ilmi walGharbah (Martyrs in Seeking Knowledge in a Foreign Country). Syuhadā'ul-'Ilmi walGharbah can be seen as semiotic symptoms. To prove that the poem of Ahmed Shawqi's Syuhadā'ul-'Ilmi wal-Gharbah as the semiotic symptoms needs theory and method. Theory is a work guide and an analysis tool to reveal the meanings contained in the poem entitled Syuhadā'ul-'Ilmi wal-Gharbah (Martyrs in Seeking Knowledge in a Foreign Country) by Ahmed Shawqi. Meanwhile, the method is how it works in revealing the meanings contained in it. The poem composed by Ahmed Shawqi is regarded as a sign because a literary work is a world in words that can be regarded as a means of communication between readers and authors. Therefore, literature can be regarded as a semiotic phenomenon (Teeuw, 1988: 43; Chamamah-Soeratno, 1991: 18; Sangidu, 2004: 18). Likewise, the poem entitled Syuhadā'ul-'Ilmi wal-Gharbah can be regarded as a semiotic symptom, namely as a signifier whose meanings (the signified) needs to be revealed.

Semiotics is a discipline that examines all forms of communication during which communication is carried out using signs which are based on sign systems or codes [S Segers, 1 1978. 
14]. Because semiotics is regarded as a science of signs or as a study of systems, rules, and conventions that enable these signs to have meaning, in this sense, there are two principles that need to be considered. The two principles are "Signifier" (Fr. Signifiant), or those that sign and "Signified" (Fr. Signifié), or those that are signed (ChamamahSoeratno, 1991: 18; Pradopo, 1995: 121; Sangidu, 2004: 18). As a sign, the meaning of a literary work (the signified) can refer to something outside the literary work itself or within itself (Riffaterre, 1978: 1).

Therefore, in order to reveal the meaning (signified) of the work, in this case, the poem entitled Syuhadā'ul-'Ilmi walGharbah as a semiotic symptom, methods were needed, namely heuristic reading method and hermeneutic or retroactive reading method. The heuristic reading method is a method done by readers by interpreting literary texts referentially through linguistic signs, such as interpreting the meaning of the word by word, phrase by phrase, or sentence by sentence or, according to (Pradopo, 1995: 7), the reading is done structurally (Riffaterre, 1978: 5); Sangidu, 2004: 19). In other words, at this stage, the readers can find the meaning (Abdullah, 1991: 8) from the word for word. Moreover, the hermeneutic or retroactive reading method is a continuation of the heuristic reading method to look for the meaning of meaning or significance. This method is a method done by readers by working continuously through reading literary texts back and forth from the first page to the last page and repeatedly in order to find the meaning of literary work, namely a poem entitled Syuhadā'ul-'Ilmi wal-Gharbah as a sign system (Riffaterre, 1978: 2; Culler, 2002: 81).

The reading technique can be done one by one from the heuristic reading first and then the hermeneutic or retroactive reading and can also be done simultaneously depending on the conditions of the literary work. In other words, the heuristic reading or hermeneutic reading can run simultaneously or together. However, theoretically, according to the scientific method to make the process of finding meaning easier to be analyzed gradually and systematically, the heuristic reading of the overall text was carried out first and followed by the hermeneutic or retroactive reading.

This research of Syuhadā'ul-'Ilmi walGharbah is a type of qualitative research with a descriptive method. For that, in explaining and describing the data in this poem, firstly reading and listening to data that contains in the poem to be recorded on the data card. The data has been collected and then classified to be selected for living in of data and living out of data. The data that have the potential to be analyzed (living in of data), immediately processed for describing and explaining by utilizing methods and techniques as stated above. After the stages of the research are implemented, it can be briefly described that in the poem, Shawqi told about a group of young Egyptians who traveled to Europe to seek knowledge at their respective 
universities. They traveled and rode a train that would take them to a place in Italy. However, their train crashed somewhere in Italy and 11 (eleven) students later died. Their bodies were brought back to Egypt and received a great welcome from the Egyptian people from various regions. This tragedy made the Egyptian atmosphere worse because it coincided with the turbulent and heated Egyptian revolution in 1920 AD. The eleven Egyptian students who died on their way to seek knowledge were categorized as martyrs who had been written in his poetry entitled Syuhadā'ul-'Ilmi wal-Gharbah (AlAyubi, 2016: 277, 283; Shalih Mathar, 2003). This tragedy gives own meaning that needs to be analyzed dan described in this study.

Based on the introduction above, the problem will be taken care and that to be answered in this research is how is the meaning of meaning of the poem Syuhadā'ul-'Ilmi wal-Gharbah in relation to the struggle for seeking knowledge in a foreign country in Ahmed Shawqi's Syuhadā'ul-'Ilmi walGharbah. So that this research aims to explore and to reveal the struggle for seeking knowledge in a foreign country so that to be emulated by future generations, especially in Egypt and generally in other countries. Therefore, the meanings contained in this poem are very important to understand, reveal, and studied further.

\section{FINDING AND DISCUSSION}

Overview of Ahmed Shawqi's Background

\section{(1868-1932)}

Ahmed Shawqi was born in Cairo in 1868 and died on October 14, 1932. He was born to both Egyptian parents. From his father, Shawqi received Arabic, Kurdish, and Circassians blood, while from his mother received Turkish and Greek blood.

Little Shawqi, at the age of 4 years, had received a book from Shaykh Salih. He studied at the al-Mubtadiyan al-Ibtidaiyyah school, then the Tajhiziyyah and Tsanawiyyah. It was in these schools that he interacted with his friends, the natives of Egypt. He knew their way of life, including sharpening his poetic skills and talents. In 1885, his father sent him to a law school to study law. This law school opened the Department of Translation was so that Ahmed Shawqi later enrolled in this department. In the translation department, he got acquainted with Sheikh Muhammad Basyuni who then trained his literary talents and encouraged him to make praise Khedive Taufiq Pasha. After graduating from law school, Khedive Taufiq Pasha chose him to enter the Palace and sent him to Europe to study law and literature in France (Jazil, 2015: 5). In France, Shawqi watched various Dramas and was connected with the literary life there. Reading the literary works of famous French writers, such as Victor Hugo, Alphonse de Lamartine, Shawqi's journey in studying was fruitful. therefore, two years after Shawqi returned to Egypt, he was chosen to be the leader of the Ifrinji (European Civilization) at the Palace, and then appointed as a poet for Khedive Abbas Pasha (Fathoni, 2007: 32; 
Poetika : Jurnal Ilmu Sastra

Vol. 8 No. 2, December 2020
Ma'diy, 2013: 5-7)

The First World War broke in 1914. Khedive Abbas Pasha was fired and replaced by Sultan Husain Kamil as his successor. Shawqi was angry and composed a qasida, monorhyme poem, containing a reproach in English. As a result, the Egyptian government exiled him to Spain. However, in his exile in Spain, he composed several qasidas containing the lost Arabic history in Andalusia. He was in Spain until 1919 AD. On his return from Spain, he changed his literary scope from the Palace to be a poet for the people, a poet who expressed all the pain and hopes of the Egyptian people, singing Egyptian National majesty. He had witnessed various events that took place in Egypt, such as the Arab revolution, British occupation of Egypt, and the nationalist movements of Mustafa Kamil and Muhammad Farid. It was during this time that He was chanting poetry of nationalism, calling for jihad and becoming a mujahid, and recording many Egyptian incidents. Besides, he also included them in his nationalistic poems and expressed various events and Arab revolutions (Shalih Mathar, 2003: 44-45).

Shawqi composed his poetry anthology in 1927 that a party was held to honor him by inviting several poets from Arab countries to give appreciation to Shawqi's verses. At this feast, Shawqi was confirmed and called the Poet of Court and, by his colleagues, Shawqi was also nicknamed AmïrusySyu'arā' (Leader of the Poets) (Hasanah, 2016; Hidayat, 2018). Hafidz Ibrahim told this with the following expression.

\begin{tabular}{|c|c|}
\hline 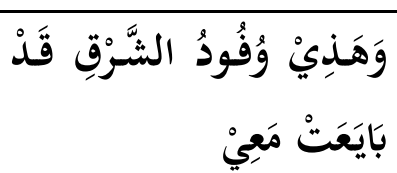 & 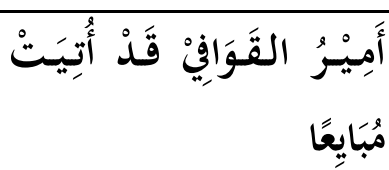 \\
\hline $\begin{array}{l}\text { And these delega- } \\
\text { tions of the East } \\
\text { have sworn alle- } \\
\text { giance with me }\end{array}$ & $\begin{array}{l}\text { Amir Qawafi has } \\
\text { been confirmed or } \\
\text { enshrined }\end{array}$ \\
\hline
\end{tabular}

Since childhood, Shawqi was good at poetry so that many poets at that time came to explore his knowledge. In 1927, Shawqi published his poetry anthology entitled Esh-Shawqiyyat (Rusmana, 2011). In addition, Shawqi's passion for literature, especially poetry and drama, encouraged him to publish a drama book entitled Al-Mashra' Cleopatra) (Ma'diy, 2013: 7-10). The meaning of one of his poetry anthologies entitled Syuhadā'ul-'Ilmi

wal-Gharbah (Martyrs in Seeking Knowledge in a Foreign Country) would be revealed by utilizing the semiotic theoretical framework and the heuristic reading and hermeneutic or retroactive reading methods as follows.

\section{Martyrdom in Seeking Knowledge}

In the first verse of the poem Syuhadā'ul'Ilmi wal-Gharbah, Ahmad Syawqi reveals a picture of martyrdom at the time of studying and seeking knowledge. Ahmad Syawqi categorizes eleven youth who died on the way to study and seek knowledge as people who were martyred, even though they have not yet studied in a foreign country. Literary and textual data relating to martyrdom in seeking knowledge indicated that it is a struggle in the way of Allah and is stated in 8 (eight) verses 
(Shalih Mathar, 2003: 43) below.

\begin{tabular}{|c|c|}
\hline الوَلِلْمَجْدِ مَا أَبْقَى مِنَ المَتَلِلِ & 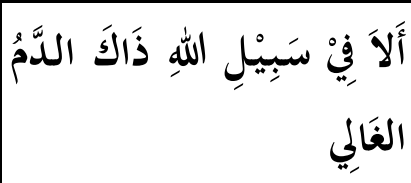 \\
\hline $\begin{array}{l}\text { ry, what } \\
d \text { of the }\end{array}$ & $\begin{array}{l}\text { s sake } \\
\text { ood? }\end{array}$ \\
\hline 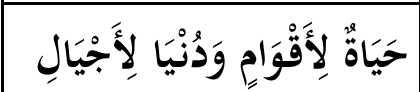 & مِنْ وَرَائَهِها \\
\hline $\begin{array}{l}\text { An ideal that will live } \\
\text { on for some nations } \\
\text { and be a new world } \\
\text { for generations }\end{array}$ & $\begin{array}{l}\text { Some of the deaths } \\
\text { occur because of the } \\
\text { ideals behind them. }\end{array}$ \\
\hline 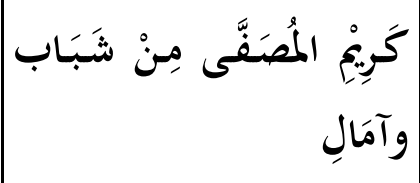 & عَلَى \\
\hline $\begin{array}{l}\text { The noble and holy } \\
\text { blood, of the youth } \\
\text { also of hope }\end{array}$ & $\begin{array}{l}0 \text { my two eyes, let } \\
\text { your eyes shed tears } \\
\text { profusely, weeping } \\
\text { over the flowing } \\
\text { blood }\end{array}$ \\
\hline 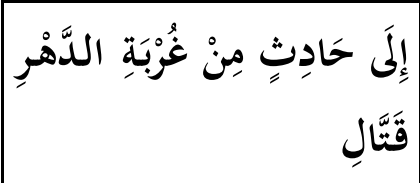 & نَاهَتْْ بِبِ الأَحْدَاثُ مِنْ \\
\hline $\begin{array}{l}\text { With an incident at } \\
\text { one time occurring in } \\
\text { a distant place, was } \\
\text { killed }\end{array}$ & $\begin{array}{l}\text { Some of the events } \\
\text { that took place in that } \\
\text { land far away, had to } \\
\text { end }\end{array}$ \\
\hline 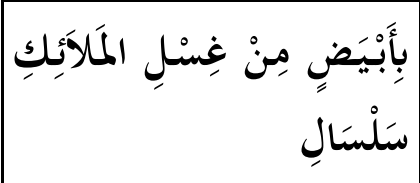 & 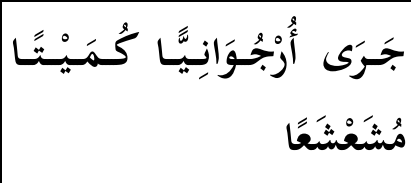 \\
\hline $\begin{array}{l}\text { The clear white one, } \\
\text { from the corpse } \\
\text { bathed by the angels }\end{array}$ & $\begin{array}{l}\text { r, purplish } \\
\text { flowed in } \\
\text { ater }\end{array}$ \\
\hline 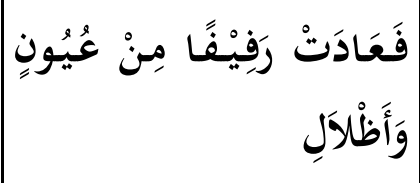 & 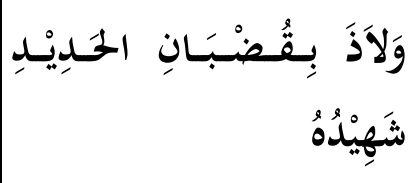 \\
\hline $\begin{array}{l}\text { So it returns as a lily } \\
\text { with springs and } \\
\text { shade trees }\end{array}$ & $\begin{array}{l}\text { vered the } \\
\text { witness }\end{array}$ \\
\hline 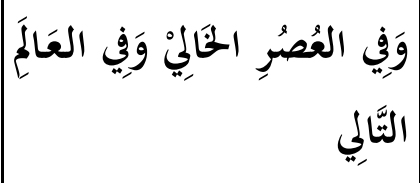 & 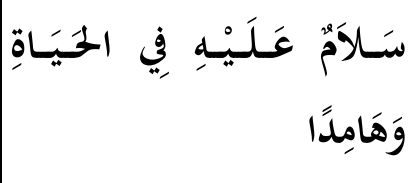 \\
\hline
\end{tabular}

Peace be also upon Peace be upon him him in the empty when he is alive and times and later, in the stretched next world

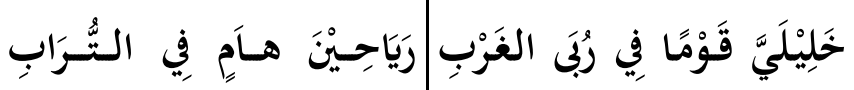
وَأَوْصَالِ وَابِقْقِيًا

Also, basil growing on 0 my beloved, my peoit, or creeping things ple, for this good plant on the ground and in that comes from the its joints west, flow it

\section{Longing for his Country}

In the next verse of the poem, Ahmad Syawqi reveals a picture of how the Egyptian people feel by the time they arrive in their country. This was disclosed by Ahmad Syawqi because they have separated far from their country. They parted ways because they aimed to study and seek knowledge in Italy. Literary and textual data relating to the longing of the Egyptians for their country are contained in 14 (fourteen) verses (Shalih Mathar, 2003: 43-44) below.

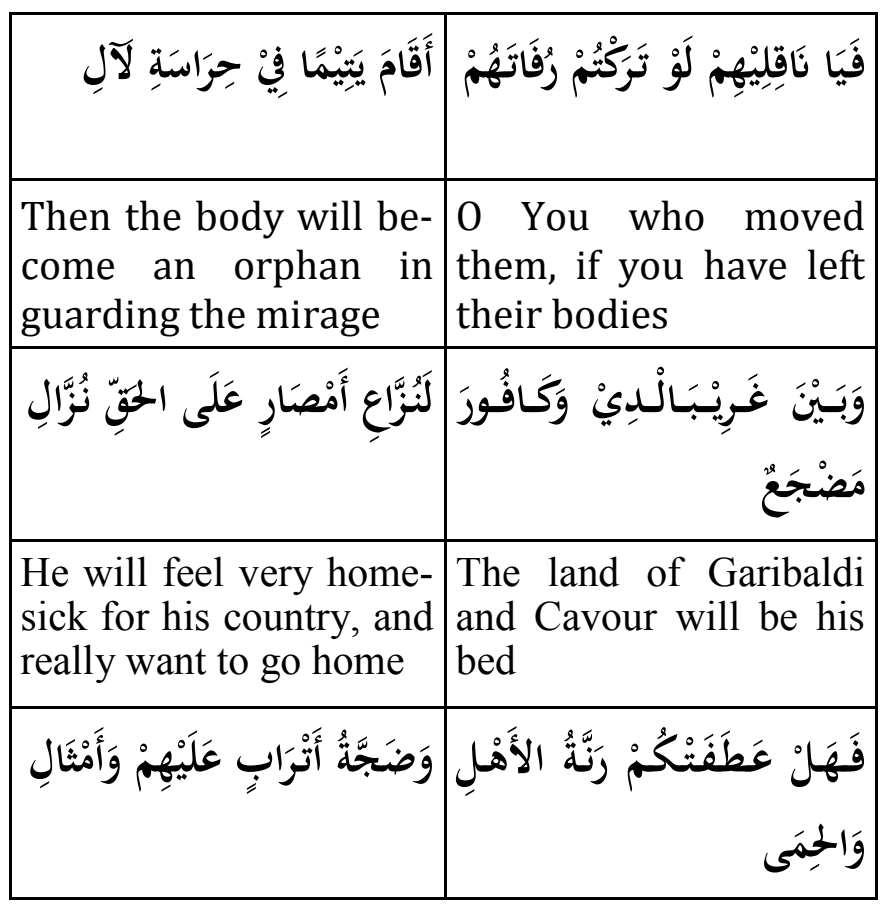




\begin{tabular}{|c|c|}
\hline $\begin{array}{l}\text { Or the screams of } \\
\text { their friends and } \\
\text { peers? }\end{array}$ & $\begin{array}{l}\text { Is it the sobs of fami- } \\
\text { ly and country that } \\
\text { have published your } \\
\text { compassion? }\end{array}$ \\
\hline 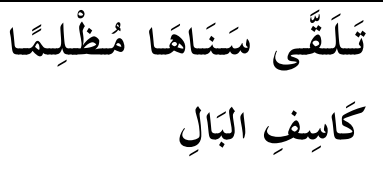 & 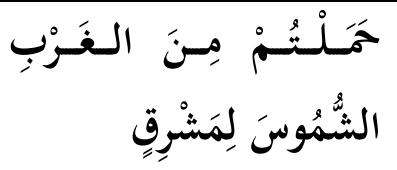 \\
\hline $\begin{array}{l}\text { Whose light was ac- } \\
\text { cepted as grievous } \\
\text { darkness }\end{array}$ & $\begin{array}{l}\text { You flank the Sun } \\
\text { from West to East }\end{array}$ \\
\hline مَدَاهاً وَلَُ تُوصَلْ ضُحَاهَا & 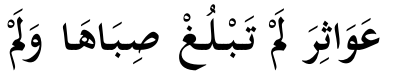 \\
\hline بِآصَال & \\
\hline $\begin{array}{l}\text { the goal. Their } \\
\text { Dhuha was not } \\
\text { reached after Asr }\end{array}$ & $\begin{array}{l}\text { The little ones caught } \\
\text { in the net, while they } \\
\text { haven't had time to } \\
\text { find what they are } \\
\text { looking for, have not } \\
\text { yet reached }\end{array}$ \\
\hline 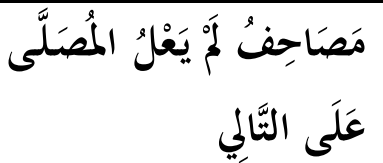 & يُطَافُ نِِِمْ نَعْشًَا فَنَعْشُشًا \\
\hline $\begin{array}{l}\text { Mushaf-mushaf, } \\
\text { with the first horse } \\
\text { that will not overtake } \\
\text { the second horse }\end{array}$ & $\begin{array}{l}\text { Their coffins were } \\
\text { carried around, one } \\
\text { by one, as if they } \\
\text { were }\end{array}$ \\
\hline 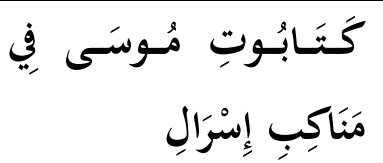 & زَتَوَابِيْتَُّ فِي الأَعْنَاقِ تَتْرَى \\
\hline $\begin{array}{l}\text { Like the ark of Mo- } \\
\text { ses on all sides of } \\
\text { Israel }\end{array}$ & $\begin{array}{l}\text { The boxes on the } \\
\text { shoulders moved } \\
\text { swiftly, emitting a } \\
\text { scent of glory }\end{array}$ \\
\hline 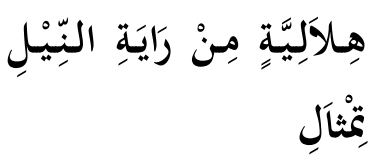 & لَةَ فِيْ حُلَّةٍ شَفَقَقِيَّةٍ \\
\hline $\begin{array}{l}\text { Decorated with a } \\
\text { crescent moon, the } \\
\text { flag of the Nile with } \\
\text { a statue }\end{array}$ & $\begin{array}{l}\text { The one covered with } \\
\text { a white cloth with } \\
\text { orange dye }\end{array}$ \\
\hline 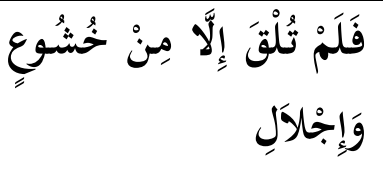 & وَأَظَلٌُْ جَلاَلْ العِلْمِ وَالْمَوْتِ \\
\hline $\begin{array}{l}\text { Which is received } \\
\text { with a special and } \\
\text { exalting attitude }\end{array}$ & $\begin{array}{l}\text { Shadowed by the glo- } \\
\text { ry of knowledge and } \\
\text { death as its messenger }\end{array}$ \\
\hline مَالِلَ مَنْزِلٍ مِنْ جِيْرَةِ الحَقِّ & تُــــارِقِ دَارًا مِـنْ غُرُوْرِ \\
\hline
\end{tabular}

\begin{tabular}{|c|c|}
\hline $\begin{array}{l}\text { eading to a house that } \\
\text { ides the truth as the } \\
\text { ncellation }\end{array}$ & $\begin{array}{l}\text { house of lies and false- } \\
\text { hood }\end{array}$ \\
\hline 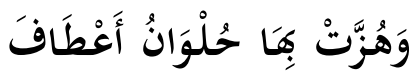 & مَ البَحْرُ \\
\hline $\begin{array}{l}\text { lake Hilwan with } \\
\text { rogance }\end{array}$ & $\begin{array}{l}\text { O horse racing arena, } \\
\text { move your jewels over } \\
\text { the ocean }\end{array}$ \\
\hline 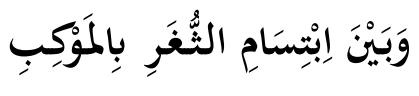 & بَيْنَ ِِيْمَاضِ العَوَاصِمِ \\
\hline $\begin{array}{l}\text { Between the smiles on } \\
\text { the lips, on the ship that } \\
\text { carried it }\end{array}$ & $\begin{array}{l}\text { He who sailed amon } \\
\text { the light of the capita } \\
\text { in Duha time }\end{array}$ \\
\hline 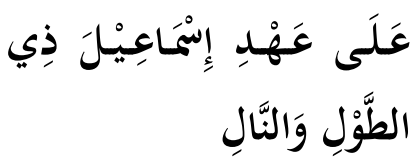 & يَي السَّبْقِ لُهَ يُرَ \\
\hline $\begin{array}{l}\text { What happened during } \\
\text { the time of Khadive } \\
\text { Ismail Pasha, who was } \\
\text { noble and loved giving }\end{array}$ & $\begin{array}{l}\text { Many events that hav } \\
\text { never been seen before }\end{array}$ \\
\hline كُكََّ & كَكَ اللهُ هــَذا الحَُطَبُ فِي \\
\hline $\begin{array}{l}\text { For what had never } \\
\text { happened before, a } \\
\text { death so heartbreaking }\end{array}$ & $\begin{array}{l}\text { To You, O Allah, this } \\
\text { utterance of incompre- } \\
\text { hension }\end{array}$ \\
\hline
\end{tabular}

\section{Unity of the Egyptian People}

At the end of this verse, Ahmad Syawqi returned to burn the spirit of the young Egyptians to remain united and not divided in the face of all obstacles and obstacles. To achieve the unity of Egyptian society, the main key that must be held is science and knowledge. Ahmad Syawqi wants Egyptian society to be a knowledgeable society and not return to the previous type of society, that is, society is under ignorance and oppression as happened in previous 
periods. Literary and textual data relating to the unity of the Egyptian people towards their country are contained in 7 (seven) verses (Shalih Mathar, 2003: 43-44) below.

\begin{tabular}{|c|c|}
\hline 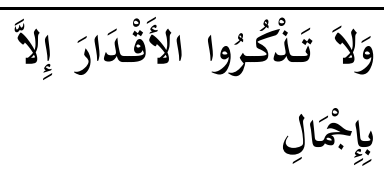 & 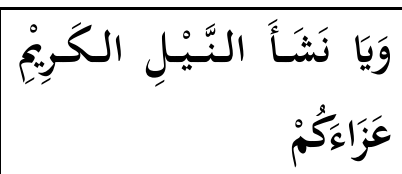 \\
\hline $\begin{array}{l}\text { Don't reveal destiny } \\
\text { other than just by the } \\
\text { beauty }\end{array}$ & $\begin{array}{l}\text { O young Egyptians, } \\
\text { builders of the Nile, } \\
\text { Your Majesty, for you } \\
\text { this condolence }\end{array}$ \\
\hline وَلَيََّ إِذَا الأَعْلَالمُ خَانَتْ & عَلَيْكُمُمْ لِوَاءَ العِلْمِمِ فَالفَوْزُ \\
\hline بِعَذَّالٍ & \\
\hline $\begin{array}{l}\text { Not to scientists who } \\
\text { betrayed him and let } \\
\text { him go }\end{array}$ & $\begin{array}{l}\text { For you, the flag of } \\
\text { knowledge, be con- } \\
\text { sistent in continuing } \\
\text { to study because vic- } \\
\text { tory is only under it } \\
\end{array}$ \\
\hline وَصَوْلِلِ مَسَـاعِ لاَ مَلَؤْلٍ & إذذا مَالَ صَفُُّ فَاَخْلُفُوْهُ \\
\hline وَلاَ آلِ & \\
\hline $\begin{array}{l}\text { who bites into his } \\
\text { ideals and do noble } \\
\text { work, not those who } \\
\text { turn away, lacking } \\
\text { and weak }\end{array}$ & $\begin{array}{l}\text { When one line of } \\
\text { seekers of knowledge } \\
\text { turns away, replace it } \\
\text { with another line }\end{array}$ \\
\hline 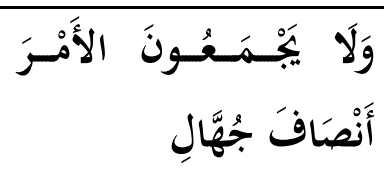 & 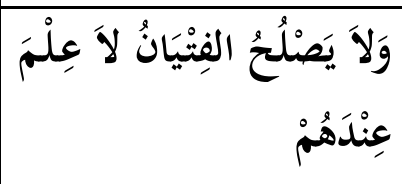 \\
\hline $\begin{array}{l}\text { A group of ignorant } \\
\text { and uneducated chil- } \\
\text { dren can't even col- } \\
\text { lect anything }\end{array}$ & $\begin{array}{l}\text { There is no use in } \\
\text { young people who are } \\
\text { not knowledgeable }\end{array}$ \\
\hline 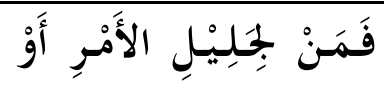 & إِذَا جَزَعَ الفِتْيَانُ فِي وَقَعِع \\
\hline مُعْضِلِ الحَالِ؟ & حَادِثٍ \\
\hline $\begin{array}{l}\text { Then we will know, } \\
\text { who is he? Is it a } \\
\text { noble child or one } \\
\text { who is just busy } \\
\text { with current prob- } \\
\text { lems }\end{array}$ & $\begin{array}{l}\text { If young people face } \\
\text { an incident }\end{array}$ \\
\hline 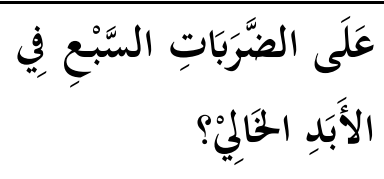 & 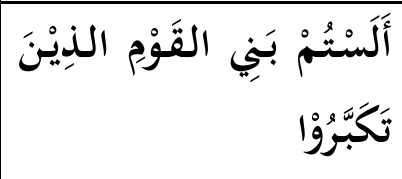 \\
\hline
\end{tabular}

\begin{tabular}{|c|c|}
\hline $\begin{array}{l}\text { Even able to face sev- } \\
\text { en calamities in the } \\
\text { past? }\end{array}$ & $\begin{array}{l}\text { Aren't you the de- } \\
\text { scendants of the peo- } \\
\text { ple who feel great? }\end{array}$ \\
\hline رَبَجَعْتُمْ لِعَمِّ فِي القَبَائِلِ أَوْ & 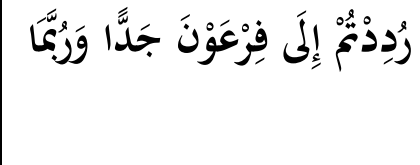 \\
\hline $\begin{array}{l}\text { You can also go back } \\
\text { to the time of your } \\
\text { uncle, the Arab tribes }\end{array}$ & $\begin{array}{l}\text { You can go back to the } \\
\text { time of your grandfa- } \\
\text { ther, Pharaoh. Or } \\
\text { maybe }\end{array}$ \\
\hline
\end{tabular}

Heuristic Reading of the Syuhadā'ul-'Ilmi wal-

\section{Gharbah Text}

As previously stated, the heuristic reading method is a reading or analysis of word for word, verse by verse, and term by term in the poem which will be semiotically analyzed. Therefore, below are the results of the heuristic reading.

\section{Meaning of Words in Verses 1-2}

The blood of these young people is seen as martyrdom because they are struggling in the way of Allah in seeking knowledge. This is done to realize glory for their nation. Their attempt with their education has led them to become martyrs in the way of Allah. They are examples that live up to high dreams. Perhaps their death in this way will awaken dreams in the souls of others. Therefore, they are role models in realizing what they are looking for by realizing the hopes for their nation and their nation's life in a new world (Gershoni_et__al____19866; Shalih Mathar, 2003: 45).

\section{Meaning of Words Verses 3-8}

The meanings of word per word in verses 3 to 8 are as follows. 


\begin{tabular}{|c|c|}
\hline تَنَكَاهَتْ الأهمرْ & To the end \\
\hline بَلَلَغَ هِاَيَتُهُ & Reached its end \\
\hline النَّوَى & Far \\
\hline الأُْْْجُوَانِيْ & $\begin{array}{l}\text { Leaning on the purple Ar- } \\
\text { juan flower. Used for a mix- } \\
\text { ture of red that resembles } \\
\text { blood because of its density. }\end{array}$ \\
\hline الكُمَيّتُ & Red mixed with black \\
\hline المُشَعْشَعُعُ & Mixed with water \\
\hline غُسْنْ & Who is bathed \\
\hline أَظْلْلَلُ & $\begin{array}{l}\text { Whe plural of the word ظل } \\
\text { which means, shade/shadow }\end{array}$ \\
\hline رَفِيْنَفا & $\begin{array}{l}\text { Daffodils, lilies, or a place for } \\
\text { trees and so on. }\end{array}$ \\
\hline رَيَاحِيْنَ & $\begin{array}{l}\text { singular form of Rayhan, one } \\
\text { type of plant that smells } \\
\text { good. basil. }\end{array}$ \\
\hline 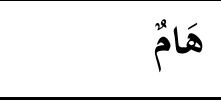 & $\begin{array}{l}\text { The plural of the word Ham, } \\
\text { reptiles }\end{array}$ \\
\hline أَوْصَالُ & $\begin{array}{l}\text { The plural of washala, joint, } \\
\text { or meeting of several bones, } \\
\text { or all bones } \\
\text { (Munawwir \& Munawwir, } \\
\text { 1984a) }\end{array}$ \\
\hline
\end{tabular}

0 my eyes, weep and flood your tears. Express your sorrow and despair, of the shed blood of those noble young people. Those who are still clean, with all their dreams and determinations, must be stopped by their death. Their blood flowed red, like the color of Arjuwan embroidered with the whiteness of water, the drops of water that fell when the angels bathed them. They are martyrs and those who are martyred are bathed by angels. Their intelligent blood flowed down the railroad iron in Italy as martyrs. To then be moved to a place, which later became their grave. A garden with springs, trees, and shade. To these holy souls, peace be upon them. Peace be upon them while they were still alive, after the death came, until later when they are resurrected. Peace be upon them when they live again after death, in the afterlife (Shalih Mathar, 2003: 45-46).

So, my brothers, get up and go to their graves. Water them with flowers and wind. Because, as in ancient Arabic myths, there will be reptiles that will come out of the heads of everyone who dies. The animal will say, "Give me water ...". The animal will be in all places, either the battlefield or the grave. therefore, the meanings of the words are as follows.

\begin{tabular}{|c|c|}
\hline رُفَاتَهُهُمْ & The body of the deceased \\
\hline Tٓل & Mirages or shadows \\
\hline 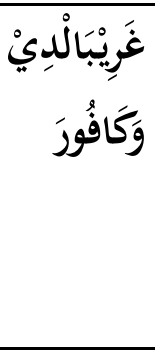 & $\begin{array}{l}\text { Two hero figures who fought } \\
\text { for Italian independence. } \\
\text { Namely: Giuseppe Garibaldi } \\
\text { (Italian Military Commander) } \\
\text { and Camillo Paolo Filippo Giu- } \\
\text { lio Benso Conte di Cavour } \\
\text { (Italian PM) }\end{array}$ \\
\hline 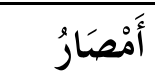 & Country \\
\hline عَطَفَتْهُهْ & Facing \\
\hline رَزَّةَّمُ & $\begin{array}{l}\text { A sad voice that comes out } \\
\text { when you sing or cry. Crying }\end{array}$ \\
\hline أَتَتَابُ & $\begin{array}{l}\text { Friend } \\
\text { (Munawwir \& Munawwir, } \\
\text { 1984b). }\end{array}$ \\
\hline
\end{tabular}

\section{Meanings of Words in Verses 9-11}

0 people who removed their bodies, you did a good deed by removing their remains and bringing them back to their country. If you left them in Italy, and you buried their bodies there, 
then you would just leave them, like in the desert. On land unknown to their family and country, in the land of Giuseppe Garibaldi (Italian Military Commander) and Camillo Paolo Filippo Giulio Benso Conte di Cavour (Italian Prime Minister) who brought independence to Italy. You have transferred them to your family, lovers, friends, and all who

\begin{tabular}{|c|c|}
\hline سناها & The light \\
\hline كَاسفَ & Sad and confused \\
\hline 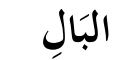 & \\
\hline & $\begin{array}{l}\text { Small animals trapped in the } \\
\text { nets of hunters and fishermen }\end{array}$ \\
\hline & $\begin{array}{l}\text { A bed or coffin that is used to } \\
\text { carry the body }\end{array}$ \\
\hline & $\begin{array}{l}\text { The horse that came first in } \\
\text { the horse race }\end{array}$ \\
\hline & $\begin{array}{l}\text { The horse that came later, or } \\
\text { after the first horse }\end{array}$ \\
\hline تَتْرَى & Move quickly \\
\hline & $\begin{array}{l}\text { The Ark is a box like the one } \\
\text { used by the mother of the } \\
\text { Prophet Musa A.S. to lay the } \\
\text { little Prophet Musa before be- } \\
\text { ing carried away into the Nile, } \\
\text { which was later found by } \\
\text { Pharaoh's family and educated } \\
\text { him until adulthood. }\end{array}$ \\
\hline & Israel \\
\hline زَكِيَّةُة & The aroma is noble \\
\hline حُحلَّةُ & Clothes \\
\hline شَفَقَيَّةُّة & White as the light of twilight \\
\hline هِلاَكِيَّة:ٌْ & $\begin{array}{l}\text { Egyptian flag embroidered } \\
\text { with crescent moon }\end{array}$ \\
\hline إِجْلاكلُ & Respect \\
\hline مِحْلاكلُ & $\begin{array}{l}\text { Falsehood } \\
\text { (Munawwir \& Munawwir, } \\
\text { 1984b) }\end{array}$ \\
\hline
\end{tabular}

have them in Egypt (Shalih Mathar, 2003: 46-
47). The followings are the meanings of the words.

\section{Meanings of Words in Verses 12-18}

You have brought their wrapped bodies from the West, Italy. They are like the sun in Eastern Egypt. However, their Egyptian family welcomed them in sorrow. The students had to face and enter into the net of death when they are young and immature. Their education is not yet perfect, their dreams have not been fulfilled.

You took their bodies around, on the streets of Cairo, in coffins after other coffins. They are like the mushaf that were carried using an ark, like the ark that was used by the mother of Prophet Moses to carry the baby of Prophet Musa to the Nile, before being found by Pharaoh's wife. Even though the Prophet Musa was part of the Children of Israel.

Their bodies were covered with a white Egyptian flag, very white with a crescent moon decoration, that is the Egyptian flag during the time of Khadive Ismail Pasha. Their families picked them up full of devotion, glorifying the

\begin{tabular}{|c|c|}
\hline الحلْبَةُ & Horses gathered for horse races \\
\hline رَفت & It appears, appears \\
\hline & $\begin{array}{l}\text { The name of the ship that carried } \\
\text { the bodies of the martyrs to } \\
\text { Egypt }\end{array}$ \\
\hline & Light \\
\hline النَّالْ & $\begin{array}{l}\text { Giving. In this stanza, there is a } \\
\text { hint about the competition held } \\
\text { at Helwan during the Khadive } \\
\text { Ismail Pasha }\end{array}$ \\
\hline
\end{tabular}




\begin{tabular}{|r|l|}
\hline الخُطَبَُ & Disaster \\
\hline المَنَايًا & $\begin{array}{l}\text { The plural form of maniyyah, } \\
\text { death. } \\
\text { (Munawwir \& Munawwir, } \\
\text { 1984b). }\end{array}$ \\
\hline
\end{tabular}

\section{Meaning of Words in Verses 19-22}

Their family had taken them on a ship called Helwan which moved gallantly, from Italy to Egypt. The ship sailed through various ports and capitals. This incident had never happened during the time of Ismail Pasha before, because of the many events that occurred in Egypt at that time. This incident never crossed anyone's mind at all. Therefore, the meanings of words per word in verses 19-22 are as follows.

\begin{tabular}{|c|c|}
\hline حُحََّالْ & No education \\
\hline جَزَعُ & Fear \\
\hline مُعْضَكَ & Problem \\
\hline 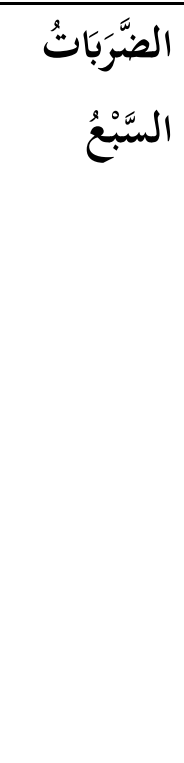 & $\begin{array}{l}\text { The signal to calamity shown } \\
\text { by the Divine Word of Allah } \\
\text { SWT and Allah tested the } \\
\text { Egyptian predecessors in the } \\
\text { past as stated in Q.S. Al-A'raf } \\
\text { [7]: 130,133). } \\
\text { Meaning: Indeed We have pun- } \\
\text { ished Pharaoh and his people } \\
\text { by bringing years of the dry } \\
\text { season and lack of fruit so that } \\
\text { they can take lessons (130). We } \\
\text { sent them typhoons (the great } \\
\text { flood), grasshoppers, fleas, } \\
\text { frogs, and blood as clear evi- } \\
\text { dence, but they still boasted, } \\
\text { and they were previously a peo- } \\
\text { ple of sin (133). }\end{array}$ \\
\hline الأَبَّدُ المَكَالِي & $\begin{array}{l}\text { Ancient time } \\
\text { (Munawwir \& Munawwir, } \\
\text { 1984b). }\end{array}$ \\
\hline
\end{tabular}

\section{Meanings of Words in Verses 23-29}

0 young men of Egypt. 0 noble children of the Nile, with my words I offer my condolence and say the destiny beautifully. You must continue consistently with victory, earnest attitude, effort, and success. To raise your country's flag, unite in one line. Strive for success without feeling lazy, bored, or putting less effort into it. Because the advancement of this world can only be obtained by knowledge and not ignorance or being semi-educated. Fear and anxiety are not needed, because what is needed is enthusiasm. You have all of that because you are the children of Pharaoh who were patient when facing An-Nawazilus-Sab'u (a seven-year famine as described in the story of Prophet Yusuf) which lasted for seven years. You are also native Arab children who believe in Allah so that you have a grandfather Pharaoh, and an Arab uncle (Shalih Mathar, 2003: 48).

\section{Hermeneutic or Retroactive Reading of the} Syuhadā'ul-'Ilmi wal-Gharbah Text

The poem entitled Syuhadä'ul-'Ilmi walGharbah (Martyrs in Seeking Knowledge in a Foreign Country) has social, scientific, psychological, and humanity contents. The poem is enriched with several artistic elements, such as sound, music, words, and depictions that are made based on the view of social facts. Therefore, this poem was composed of various social bases and able to move the various parts that make up the building of the qasida. The qasida was also expressed on a special occasion, that a group of students was sent to Europe to study 
and seek knowledge at several European universities. On one occasion, they had to take a train in Italy. However, when this train arrived at the Udine city of Italia, the train had an accident which caused 11 (eleven) Egyptian students to die. Their bodies were then brought back to Egypt and captured the attention and provoked the emotions of the Egyptian people (Shalih Mathar, 2003: 49).

The incident just flowed and was spontaneously expressed into a long string of poems. It was expressed out of himself who was sad to witness what happened to the children of his nation who died to realize his hopes in seeking knowledge. This sadness was also felt by Egyptians from various circles of life in the midst of various sad situations of Egypt, from efforts to stop colonialism to the particular situation of Egypt such as ignorance, backwardness, and social diseases. All of them were the situations encountered by the Egyptians in the 1919 revolution (Ata, 1955: 70-71). Shawqi, who was bewildered by the condition of his country, was even more shocked when he heard of the accidents on 11 (eleven) Egyptian students in Italy. Therefore, Shawqi composed a qasida ritsa' (Ghardhu Ritsa'). Ancient Ghardu in old Arabic literature aimed at expressing the kindness of people who died in this world to remember them and the atmosphere of Egypt, with 2 (two) primary aims, namely (1) Delivering the news of the death of young Egyptians who died while seeking knowledge, and (2) ) Advising young people to do their best for their nation (Shalih Mathar, 2003: 49-50).

Therefore, in the verses 1-27, Shawqi conveyed the news about the death of several martyrs while seeking knowledge. Speaking about this shocking incident and its impact on the Egyptians, Shawqi said, "That the blood of the young people who were killed in this incident was a blood that was very expensive and very precious. They went and passed away in the way of Allah and were on the way of glory."

Ahmed Shawqi was a man who encouraged young Egyptians to reach for their future when others could only face such glory with tears. These young Egyptians died on their way to seek knowledge in an accident that made them martyrs in a place far from their country. Their blood spilled all over the railroad iron. We could only offer our condolence to them, condolence from the Egyptian people for them. The announcer of the news of this death had announced their death to all corners of Egypt, from West to East so that news of this death spread to mothers, fathers, the moon, the wind, and others and all became tears for everyone (Haykal, 1984: 13; Shalih Mathar, 2003: 50).

They departed from Egypt with their respective hopes. However, it seemed a cruel twist of fate that they died at a very young age. Now they slept in a strange land. They did not die in their own country. The delivery of their corpses to Egypt, their precious homeland, was luck. They were brought from the West and the sun of knowledge was with them. The nation's children disappeared with their arrival. They 
went out alive and returned in coffins which the people carried on their shoulders, wandering all over the place, like Moses' ark of the covenant from the Children of Israel. Their bodies were put in boxes and covered with the holy state flag. In short, they had received two greatness, namely the majesty of knowledge and the majesty of death. They left the house full of pretense to the real house (Shalih Mathar, 2003: 50).

Egypt had never seen such discussions during the time of Khadive Ismail Pasha. However, this was the hand of fate and nothing was amazing about the death of a young person. What was amazing was our weak and helpless life. Everyone hoped for the young, while the older ones relied on their hopes for death, which could arrive at any time. Shawqi wished to young people in Egypt, who would become a symbol of sincerity and possibility.

Ahmad Shawqi showed his advice to young people, by encouraging them to seek knowledge and not to worry about fate. Death was something that would definitely happen to anyone. Young people had to mobilize their souls and bodies to serve their country, and not be afraid of the tragedy that might come their way. The poet through his verses also reminded everyone of the profound meaning of this incident, which would make them put forth their endeavors, giving their souls and bodies to serve their country, Egypt. They were the descendants of great nations, both the Pharaohs and the Arabs. These young people had to return to the glo- ry of Egypt once again. Their grandparents had been patient when they found a lot of deterioration, like the seven years of famine that the Egyptians had to experience in the era of Pharaoh, Egypt in the era of Prophet Joseph, which was called Nawazil As-Sab'u, or a heavy calamity that lasted for seven years (Shalih Mathar, 2003: 51).

Meanwhile, in terms of music, this poem uses a long bachr, with a long tafa'il as follows.

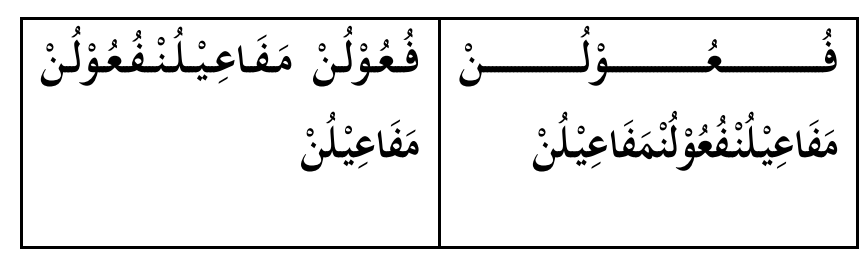

The above bachr is in accordance with the atmosphere established by the qasida or poem, which gives him a considerable opportunity to express whatever he wants, such as ritsa' (elegy), telling stories, and munasabah (the source from generation to generation). Bachr also provides space because it provides opportunities for poets to offer advice following the atmosphere established by the poetry. The words used by this poem are a mixture of various scientific disciplines, such as diction of crying and word expressions below.

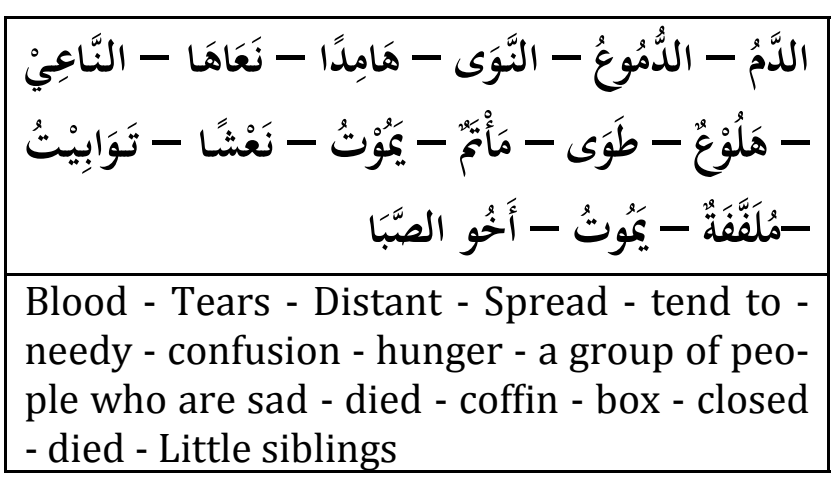


The words used above are in accordance with qasida or poetry and an expression of sadness that shows a surprising atmosphere as a continuation of the journey and initial purpose. The purpose of these two Shawqi's verses is like an invitation to cling to glory and strive to obtain it. The words used for these other scientific disciplines are as follows.

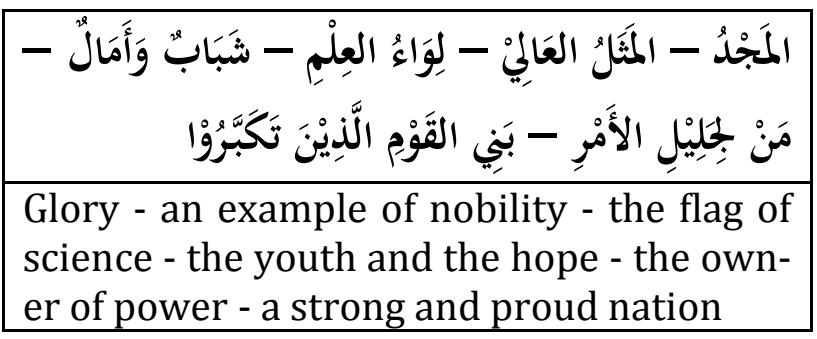

These words show the meanings of strength, determination, and fortitude of the Egyptians when it comes to dealing with events like these. They will accumulate all their precious wealth for higher aims. Their young people will present and become evidence and advice for all. All of this is proof that the Egyptians can get out of their sorrow, set and realize their goals and hopes for a better future. They will be willing to be patient and endure whatever happens. In his expression, the poet makes use of several isti'arah (metaphor) as in the following example.

\begin{tabular}{|c|c|}
\hline $\begin{array}{l}\text { For a more eternal } \\
\text { Glory as an example } \\
\text { of nobility }\end{array}$ & 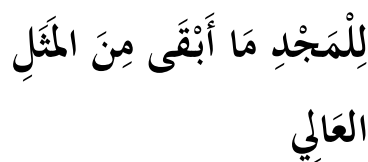 \\
\hline $\begin{array}{l}\text { Some of the deaths } \\
\text { are caused by ideals }\end{array}$ & بَعْضُ المَنَايًا هِمَّةٌٌْ \\
\hline
\end{tabular}

\begin{tabular}{|c|c|}
\hline $\begin{array}{l}\text { Closed and moving } \\
\text { from West to East }\end{array}$ & 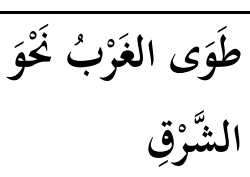 \\
\hline $\begin{array}{l}\text { A group of women who } \\
\text { are sad and cry over } \\
\text { someone's death }\end{array}$ & مَنَاحَةُ أَقَمْارِ \\
\hline 0 a racing $p$ & فَيَ \\
\hline
\end{tabular}

The examples above are isti'arah makniyyah, which is a metaphor that mentions the part of the musyabah (something that has another meaning) and discards the musyabbah bih (which is likened) which tends to make $m a-$ naya (death) and majdu (glory) have human character. This means that the use of human characters in isti'arah makniyyah is due to the influence of the poet's surprise at the news of the death of these Egyptian students in Italy. Ahmed Shawqi was shocked when he heard the news that happened to students, namely humans, so he described it by turning inanimate objects or other words into human-like characters, such as when Shawqi made tasybih (simile) in two single verses below.

\begin{tabular}{|c|c|}
\hline 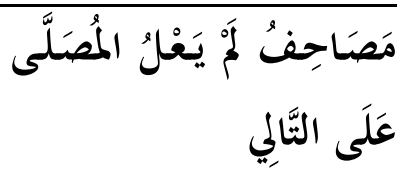 & كَأَنَّهُْْ \\
\hline $\begin{array}{l}\text { Mushaf-mushaf, with } \\
\text { the first horse that } \\
\text { will not overtake the } \\
\text { second horse }\end{array}$ & $\begin{array}{l}\text { Their coffins are } \\
\text { carried around, one } \\
\text { by one. As if they } \\
\text { are }\end{array}$ \\
\hline كَتَابُوتِ مُوسَى فِي مَنَاكِبِ & تَوَابِيْتُ فِي الأَعْنَاقِ تَتْرَى \\
\hline ل إِسْرَالِ & \\
\hline $\begin{array}{l}\text { Like the ark of Moses } \\
\text { on all sides of Israel }\end{array}$ & $\begin{array}{l}\text { The boxes on the } \\
\text { shoulders moved } \\
\text { swiftly, giving off a } \\
\text { scent of glory }\end{array}$ \\
\hline
\end{tabular}


The form of tasybih (simile) above considers the coffins carried on the shoulders of these men as despair and suffering. Therefore, this qasida or poem was composed of the poet's view of the reality he met and showed the nation's need to get out of the crisis and the harsh reality he had, namely the British occupation of Egypt that had lasted too long. This long occupation showed Egypt's need for help to get out of a situation of ignorance and backwardness. Furthermore, this nation sent its children to study abroad in order to rid this country of ignorance and backwardness. However, fate did not allow them to finish what the young people had to do in a faraway country. Fate buried them in a place far from the land where they were born. However, there were great hands willing to carry them back to their countries. This was becoming a harsh reality, but it existed and happened. This incident was an example of what was happening to Egypt at that time, which was how this nation at that time was drawn to become a great symbol of the hope of a nation that was buried alive (Aksan, 1956: 12; Shalih Mathar, 2003: 51).

\section{CONCLUSION}

The poem entitled Syuhadā'ul-'Ilmi walGharbah (Martyrs in Seeking Knowledge in a Foreign Country) written by Ahmed Shawqi contains meanings that could influence and arouse the enthusiasm of Egyptian youth to become a developed and independent nation from British colonialism. Therefore, the Egyptian government sent young people to study in western countries in the hope that after they were all successful they would return to Egypt to build their country and nation. However, the reality was that these young people had an accident while taking the train and eleven students died while struggling to seek knowledge in a foreign country. This was what made the Egyptian people experiencing deep sorrow, like the seven-year famine during the time of Prophet Yusuf.

It was this incident that prompted Ahmed Shawqi to compose and write a poem depicting the struggle of Egyptian youth in seeking knowledge in a foreign country. Of course, this poem is also a historical record and it is hoped that the next generation can read it to emulate Egyptian youth who died while seeking knowledge. Therefore, it is expected that the next young generation will have high enthusiasm in seeking knowledge in order to develop the state and nation to prevent ignorance, poverty, and occupation.

The writer argues that mastery of Science and Technology is the main key to build the strength and competitiveness of a nation in order to produce value-added products and provide a competitive advantage so that a country can develop and develop rapidly. For this reason, Egypt has a strong desire to send its young people to study in order to catch up with the developed countries.

The research results presented in this arti- 
cle are expected to make a positive contribution, especially for Indonesian youth to be enthusiastic about studying and seeking knowledge and mastering science and technology so that to build a superior Indonesian nation that can be respected by other countries. Only by mastering science and technology, the Indonesian nation will be able to develop rapidly and be on par with other countries.

The novelty that can be stated in this article from this research that has been carried out is that the writer has succeeded in clearly capturing the difficulties faced by the society and nation so that literature can be said to be a mirror and a reflection of the society. More knowledgeable people see things from the positive side. In their view, not a single event in this world is wasted, and everything must have its benefits. Therefore, it is hoped that all young people, especially Indonesians, will be enthusiastic in studying, seeking, and mastering science and technology for the advancement of society and nation in the future.

\section{REFERENCES}

Abdullah, I. T. (1991). Hikayat Meukuta Alam: Suntingan Teks dan Terjemahan beserta Telaah Struktur dan Resepsi. Jakarta: Intermasa.

Aksan, A. (1956). Krisis di Timur Tengah

(Mesir): Kumpulan Diskusi-diskusi. Yogyakarta: UGM Press.

Al-Ayubi, S. (2016). Pengaruh Perang Dunia II Terhadap Revolusi Mesir 1952. Buletin Al -Turas: Mimbar Sejarah, Sastra, Budaya dan Agama, XXII(2), 277-283.
Al-Qur'an. (2016). Al-Qur'an dan terjemahnya: QS. Al-Mujadalah [58]:11. Jakarta: Kementerian Agama Republik Indonesia.

Ata, M. M. (1955). Egypt Between Two Revolution. Cairo: Emprimerie Misr S.A.E.

Culler, J. D. (1981). The Pursuit of Signs: Semiotics, Literature, Deconstruction. London and Henley: Routledge and Kegan Paul

Fathoni, A. A. (2007). Leksikon Sastrawan Arab Modern: Biografi dan Karyanya. Yogyakarta: Datamedia.

Gershoni, I., Gēršônî, Y., \& Jankowski, J. P. (1986). Egypt, Islam, and the Arabs: The Search for Egyptian Nationhood, 1900-1930. Oxford: Oxford University Press.

Hasanah, J. (2016). Makna Puisi "al-Matariyyatu Tatakallamu" dalam Antologi Asy- Syauqiyyat Karya Ahmad Syauqi: Analisis Semiotik. [B.A. Thesis, Arabic Literature, Faculty of Cultural Sciences, Universitas Gadjah Mada].

Haykal, M. Hasanayn. (1984). Anwar Sadat: Kemarau Kemarahan. Yogyakarta: PT Grafitipers.

Hidayat, M. (2018). Unsur Intrinsik Dan Ekstrik Puisi Ghazal Karya Ahmad Syauqi. [B.A. Thesis, Arabic Literature, Faculty of Humanities, University of Indonesia]

Jazil, A. (2015). Ahmad Syauqi Sang Pangeran Penyair. https:// www.academia.edu/39080465/

AHMAD_SYAUQI_SANG_PANGERAN_PENYAIR. Accessed on Wednesday,18 November 2020, at 13:59.

Ma'diy, A. C. (2013). Asy-Syauqiyāt: Al-A'mālusySyi'riyyah. Al-Qāhirah: Dārul-Chulūd.

Munawwir, A. W., \& Munawwir, Z. A. (1997). AlMunawwir: Kamus Arab-Indonesia. Surabaya: Pustaka Progressif Publisher.

Nasrullah, N. (2018). Kisah Para Ulama Menuntut Ilmu. Republika.co.id, pp. 1. https://republika.co.id/berita/pdwjln313/ kisah-para-ulama-menuntut-ilmu, accessed on Monday, 29 June 2020, at 07:00.

Pradopo, R. D. (1991). Beberapa Teori Sastra, Metode, Kritik, dan Penerapannya Yogyakarta: Pustaka Pelajar.

Rahman, B. (2011). Perkataan Imam Syafi'I. Darunnajah, pp.1. https://darunnajah.com/ perkataan-imam-syafii-4/. Accessed on Monday, 29 June 2020, at 07:30. 
Riffaterre, M. (1978). Semiotic of Poetry. London: Indiana University Press, Bloomington.

Rusmana, D. (2011). Pembagian Sastra Mulim Pada Masa Awal. Accessed on Thursday,https://

dadanrusma-

na.wordpress.com/2011/07/13/

pembagian-sastra-muslim-pada-masaawal/2nd July 2020, at 11:00.

Sangidu, D. (2004). Penelitian Sastra: Pendekatan, Teori, Metode, Teknik, dan Kiat. Penerbit Jurusan Yogyakarta: Sastra Arab Fakultas Ilmu Budaya UGM.

Segers, R. T. (1978). The Evaluation of Text. Lisse: The Peter de Ridder Press.

Shalih Mathar, S. 'Athiyyah. (2003). FunūnulAdabil-'Arabiy: Ru'yatu Naqdiyatisy-Syi'ri. Al-Qāhirah: Maktabatul-Ādāb.

Sholikhudin, A. M. (2016). Politik Pendidikan Islam Masa Modern Membaca Gagasan Tokoh di Negara Turki, India, dan Mesir. Al-Murabbi, 1(1), 154

Soeratno, S. C. (1991). Hikayat Iskandar Zulkarnain: Analisis Resepsi (1 ${ }^{\text {st }}$ Edition). Balai Pustaka.

Teeuw, A. (1988). Sastra dan Ilmu Sastra: Pengantar Teori Sastra. Jakarta: Pustaka Jaya.. 